\title{
Locating Heidegger's Kotoba between Actuality and Hollowness: the Way towards a Thinking Conversation with Japanese Philosophy
}

\section{Onur Karamercan ${ }^{1}$}

Received: 5 March 2021 / Revised: 1 August 2021 / Accepted: 4 August 2021 / Published online: 13 August 2021

(C) The Author(s), under exclusive licence to Springer Nature Switzerland AG 2021

\begin{abstract}
What is the philosophical significance of Heidegger's interpretation of the Japanese notion of kotoba (言葉) for Japanese philosophy? Was his conversation with Tezuka Tomio a real dialogue or not? To answer to these correlated questions, I elucidate Heidegger's 1954 essay "A Dialogue on Language” by following a topological mode of thinking, and I inquire into the way-making of a "thinking conversation". First, I problematize whether Heidegger engaged in a genuine dialogue with Tezuka. To that end, I distinguish the hermeneutic horizon of the actual encounter between Tezuka and Heidegger from Heidegger's essay which places Tezuka (the Japanese) and Heidegger (the Inquirer) in a fictional philosophical conversation. Second, I argue that Heidegger's topological method of interpretating kotoba can be read as a poetic means of thematizing East-West dialogue. Third and finally, exploring the topological sense of kotoba, I engage with third generation Kyoto School thinker Ueda Shizuteru's idea of "hollow words" of language, situated in a twofold view of the world. I conclude that the true character of Heidegger's conversation with Tezuka can be identified neither in Heidegger's "actual" encounter with Tezuka, nor merely in Heidegger's "hollow" essay. Departing from Ueda's account of kotoba, it appears that a genuine conversation with language can be located in the dialogue of actuality and hollowness, which finds it expression in poetic language.
\end{abstract}

Keywords kotoba $\cdot$ Tezuka Tomio $\cdot$ Martin Heidegger $\cdot$ Japanese philosophy $\cdot$ Ueda Shizuteru

Onur Karamercan

onur.karamercan@utas.edu.au

109 rue Anatole France, Levallois-Perret 92300, France 


\section{Introduction}

What is the philosophical significance of Heidegger's interpretation of the Japanese notion of kotoba (言葉) for Japanese philosophy? Was his conversation with Tezuka Tomio a real dialogue or not? To answer to these correlated questions, I elucidate Heidegger's essay "A Dialogue on Language" by following a topological mode of thinking, and I inquire into the way-making of a "thinking conversation". First, I problematize whether Heidegger engaged in a genuine dialogue with Tezuka. To that end, I distinguish the hermeneutic horizon of the actual encounter between Tezuka and Heidegger from Heidegger's essay which places Tezuka (the Japanese) and Heidegger (the Inquirer) in a fictional philosophical conversation. Second, I argue that Heidegger's topological method of interpretating kotoba can be read as a poetic means of thematizing East-West dialogue. Third and finally, exploring the topological sense of kotoba, I engage with third generation Kyoto School thinker Ueda Shizuteru's idea of "hollow words" of language, situated in a twofold view of the world. I conclude that the true character of Heidegger's conversation with Tezuka can be identified neither in Heidegger's "actual" encounter with Tezuka, nor merely in Heidegger's "hollow" essay. Departing from Ueda's account of kotoba, it appears that a genuine conversation with language can be located in the dialogue of actuality and hollowness, which finds it expression in poetic language. ${ }^{1}$

The main hypotheses of my arguments are the following: (1) In order to evaluate whether Heidegger engaged in a genuine dialogue with Japanese philosophy, one must examine his idea of a "thinking dialogue". (2) Since any dialogue takes place in and of language, one must investigate the way in which the language of the dialogue determines the nature of the dialogue. To test my arguments, I focus on Heidegger's dialogue 1953/54 essay "A Dialogue on Language", 2 which is where we find the definition of a genuine philosophical dialogue. Following Heidegger and Tezuka's indications, an authentic philosophical conversation means awakening to the event of stillness, attending to that which is hinted in the conversation without being objectified. In topological terms, it is an act of "making space" rather than "taking up space" by letting the stillness of language speak through the interlocutors. This is contrary to the general idea of dialogue in the Western philosophy, usually considered simply as

\footnotetext{
${ }^{1}$ Here I would like to offer to the reader an alternative order of reading the article. Those who are more interested in the philosophical argumentation as to why Heidegger's interpretation of kotoba is located between actuality and hollowness, can read the fifth and last section entitled "5. Ueda's kotoba: The Twoway Movement in Language" (starting on page 13) immediately after the section entitled " 2 . Distinguishing the Two Dialogues: The Meeting in Freiburg and Heidegger's Essay" (starting on page 5). The reason I did not organize the article accordingly has two reasons: first, I believe that in order to do justice to the core matter of Heidegger's essay on kotoba, which is the occurrence of stillness in a thinking dialogue that does not objectify its subject matter, no conception of language should be provided in advance. In other words, Heidegger's idea of a dialogue with Japanese philosophy cannot be separated from the "way" of the dialogue itself. Second, considering that historically it is Ueda who engages with Heidegger's notion of being-in-the-world and language, it is more fitting to place Ueda's account after first having discussed Heidegger. Nonetheless, the alternative reading that I have suggested above could show more directly why I emphasize the need to distinguish the actual encounter between Heidegger and Tezuka from Heidegger's philosophical essay, as I use Ueda's scheme of making sense of poetic language as a way to the bridge between actuality and hollowness; world and the hollow expanse.

${ }^{2}$ References to Heidegger's Unterwegs zur Sprache (On the Way to Language) (1985) will be abbreviated as $U S$, followed by the page numbers first in the German, then in the English translation separated with a slash.
} 
mutual speech and simultaneous self-expression. In that regard, there is a need to examine to what extent Heidegger's interpretation of the Japanese word kotoba ${ }^{3}$ emerges from a genuine dialogue with Tezuka. Following that, I will explore Ueda's account of language in the last section of the article, which will help me situate Heidegger's dialogue with Tezuka and Japanese philosophy in the interplay of the actuality and the hollowness of language.

\section{Heidegger and Japanese Philosophy: A Conversation?}

Determining the nature of the philosophical exchange between Heidegger and Japanese philosophy is a complicated task. ${ }^{4}$ Heidegger had close contact with East Asian philosophies already starting from the 1920 s, as he received many visiting Japanese students to attend his lecture courses. ${ }^{5}$ Insofar as Heidegger's thought is a thinking of the overcoming of Western metaphysics by bringing it back to its own limits (US 103/20), its link with the Kyoto School (Kyōto-gakuha) in Japanese philosophy holds a special place. It can be argued that the Kyoto School, which originates from the philosophical dialogue between Nishida Kitarō and Tanabe Hajime, emerges as a series of responses to the cultural, historical, ideological and technological hegemony of the Western ontology, ethics and logic. In that sense, the idea of the overcoming of nihilism is central to both Heidegger and many Kyoto school thinkers. The Kyoto School philosophers offered critical interpretations of Heidegger's philosophy, as can be observed in

\footnotetext{
$\overline{3}$ As discussed by Marra (2004) and Ma (2007), Watsuji Tetsurō offers one of the first comprehensive interpretations of the word kotoba.

${ }^{4}$ Heisig clarifies the hermeneutic ground and horizon of that very dialogue, as he writes: "in a sense (...) the "east" that the Kyoto philosophers set up against the "west" they had constructed for themselves was also something of an invention" (2001: 271). Indeed, this would be an invention that constantly interprets "the other" from the standpoint of its "own" self-interpretation whose hermeneutic conditions are already preestablished. Hence, the East-West dialogue today cannot depend only on the so-called "cross-cultural" dialogues, if that solely implies the inter-subjective confrontation of two worlds radically separated from one another, since the boundaries of those worlds are neither well-defined nor fixed.

${ }^{5}$ Some critics indicate that Heidegger's position concerning the possibility of an East-West conversation is problematic. For instance, Ma argues that according to Heidegger the European languages seem immune to "corruption" (Ma, 2007: 172). What that implies is that it is only the Western logos that is capable of distorting the Eastern spirit, but not the other way around. According to this distorted power dynamic, the latter is represented as weak, passive and receptive, while the former is powerful, transformative and influential. Thus, Heidegger seems to make sense of the intercultural relation at issue as an asymmetric one. However, this is not the only difficulty. Graham Parkes offers the following remarks in his Rising Sun Over Black Forest: "While the documentation that would decide the question appears to be lacking, there is one consideration that militates in favour of the possibility that Heidegger learned of, and was influenced by, the idea of nothingness that was being developed by Nishida during the 1920s — and which would come to assume, in the form of "absolute nothingness", a central place in the philosophy of the Kyoto School" (May, 1996: 93). Accordingly, if Tanabe Hajime, who was a student in Freiburg at the time to study with Husserl and Heidegger, disseminated Nishida's ideas in the 1920s, it is possible that initially it was not Heidegger who had an influence on East Asian philosophers, but on the contrary, it was Heidegger who developed key aspects of his philosophy with strong influences from them. After all, as reported by Inaga (2013), Heidegger's very idea of in-der-Welt-sein (being-in-the-world) may have been a borrowing from Okakuro Kakuzō's 1906 work The Book of Tea (Cha no hon), a Daoist idea stemming from Zhuangzi. Accordingly, it was Itō Kichinosuke who first gave the book to Heidegger, and it is possible that Heidegger made a free use of that term. For more on this, see Bret Davis's "Heidegger and Asian Philosophy" (Davis, 2013).
} 
the thought of Nishida Kitarō, Tanabe Hajime, Watsuji Tetsurō -who were students of Raphael von Köbel (Ma, 2007: 11)-, which paved the way for the long and fruitful philosophical debate between Heidegger scholarship and Japanese philosophy.

Still, one might ask: why was Heidegger so appealing for the Kyoto School philosophers, especially given the exclusive nature of Heidegger's understanding of the Western history of metaphysics? Likewise, how come so many Heidegger scholars come into close contact with Japanese philosophy? According to Heidegger, the possibility of restoring the history of the West - a history of forgetfulness of the question of being-depends on experiencing the so-called historical dialogue between the Greeks (where Western philosophy flourished through thinkers such as Anaximander, Heraclitus and Parmenides) and the Germans (where Western philosophy comes to its end through Nietzsche's thought). ${ }^{6}$ Despite this onto-historical reading that Heidegger develops in the 1930s and 40s, and continues to express -though more sparinglyeven as late as the 1950s (for instance Der Spiegel interview), there is also another, and much more inclusive vein of thought that comes to the fore in his later philosophy, which is more promising for a dialogical mode of reflection.

It is plausible to think that Heidegger's later "poetic thinking", as an explicit confrontation with the origins of Western philosophy via a reconsideration of the essence of language, has proved to be an important bridge between him and Japanese thought. This new manner of thought that he developed in the $50 \mathrm{~s}$ and early $60 \mathrm{~s}$, which shows many similarities to Zen thinking, has drawn much interest from the third and fourth generation Kyoto school thinkers such as Ueda Shizuteru, Tsujimura Kōichi, and Ōhashi Ryōsuke. These thinkers have especially engaged with Heidegger's later thought, more so than their predecessors such as Nishida, Nishitani and Tanabe (Krummel, 2013). According to Heidegger, the overcoming of nihilism, or Gestell as the essence of modern technology, first requires a transformation of our relation to language. The overcoming at issue requires a hermeneutic re-orientation vis-à-vis the destructive nature of our age that is defined by the endless "will to will" (Davis, 2007: 148) and limitless machination, which also enframes language. We must learn anew how to "say" things by listening to language itself without determining language solely as the tool of communication. This is related to Heidegger's idea of being as "letting" (lassen), which leads to his thought of Gelassenheit, namely "letting-be", or "releasement". As such, a conversation with language must take place in the region of "letting-be", so that we can make sense of what it means to "think" via language in a new manner.

In that line of thinking, one of the topics that come to the fore in Heidegger's later philosophy is the nature of a philosophical dialogue, or a conversation (Gespräch), between different "houses of being" (US 85/5). Although Heidegger did not speak any

\footnotetext{
${ }^{6}$ Commentators such as Mizoguchi find the basic underpinnings of Heidegger's reading disputable (1987: 198). This is important especially considered within the context of the idea of "world philosophies". What should be the language that determines the core matter of "philosophy"? Morisato's remarks on this issue are worth noting for opening to discussion different definitions and descriptions of what philosophy is and how the very act of thinking is to be conceived, especially with regard to the Europeanization of "philosophy" by (Morisato, 2019: 23-24).
} 
East Asian languages, ${ }^{7}$ his interest in learning about Chinese (Hsiao, 1987: 98) and Japanese (Tezuka, 1996: 62) words, concepts and philosophical ideas is well known. It is precisely in that context that re-interpreting the meaning of "language" from the point of view of diverse linguistic backgrounds appears to be essential. ${ }^{8}$ Heidegger himself began to realize the necessity of engaging with Asian philosophies in the 1950s, which suggests a change in his earlier position from the 1930s and 1940s. In his On the Way to Language, Heidegger explicitly mentions the notion of dao (道) as the "way" of thinking and being, even if only in passing (US 187/92), which has drawn the attention of contemporary cross-cultural thinkers (Davis et al., 2011: 4). Nonetheless, what still needs to be questioned here regarding the idea of a genuine dialogue with Asian philosophies, and more specifically with the Kyoto School in Japanese philosophy, is the following: Does "the foreign", as mentioned in The Ister lecture courses in 1942, remains only a passage to one's own (Heidegger, 1993), or does engaging with the foreign also appropriate us in a way that it determines how we make sense of our own? Examining the 1953/54 essay "A Dialogue on Language" will help us determine whether Heidegger's attempt to get in a dialogue with Japanese culture and philosophy can be considered to be a successful attempt. In that regard, the language of that conversation, as the site of that hermeneutic re-orientation between Heidegger and Japanese philosophy, must be examined.

\section{Distinguishing the Two Dialogues: The Meeting in Freiburg and Heidegger's Essay}

Tezuka Tomio (1903-83), who was a professor in German literature at the Tokyo University, met with Heidegger at the end of March 1954 in Freiburg (Tezuka, 1996: 61). Although the intended topic of their conversation was the significance of presentday Christianity, they went on to talk about many other subjects relating to Japanese arts, philosophy, language and culture, including prominent figures like Kuki Shūzō and Suzuki Daisetsu. Tezuka already had a profound understanding of Heidegger's thought of language and poetry, thus, he wanted to hear from Heidegger more on Rilke's poetry, while Heidegger wanted to learn more about Japan, Zen thinking and Japanese language (Tezuka, 1996: 62).

The meeting results in somewhat conflicting accounts: first, Heidegger's philosophical essay, which I will examine, and second, Tezuka's bibliographical report entitled “An Hour with Heidegger", published in Japan in 1955. May claims that Tezuka's report is a valuable document, writing: "in so far as it figures in a series of

\footnotetext{
${ }^{7}$ In view of this, Lin Ma rightfully asks: "What is prima facie bewildering is that, if Heidegger considers that a "sufficient" discussion of East Asian languages is of crucial importance, if he deems that East Asian thought can make important contributions to a thinking beyond traditional metaphysics, if he attaches importance to hearing things in their original tongue, why, instead of taking sufficient initiative to learn a bit more about these languages, for a long stretch of years, he reiterates from time to time his ignorance of the original East Asian languages?" (Ma, 2007: 145).

${ }^{8}$ As Bret Davis remarks (2020: 47), Kida Gen's idea of “anti-philosophy” (han-tetsugaku), which considers philosophers like Nietzsche, Heidegger and Derrida in the same league of anti-Platonism, (Kida, 2014: 50-51) is thought-provoking. While this is not necessarily a novel approach, formulating "anti-philosophy" as a negation of "tetsugaku", which is the literal Japanese translation of the Greek word philosophia as "love of wisdom", has important implications for what "Japanese philosophy" means.
} 
consequential conversations Heidegger had with East Asian scholars. It also shows how highly Heidegger valued East Asian culture and how deeply it interested him" (1996:12). Indeed, a reader who lacks an overall idea of Japanese culture, language and philosophy, with no access to the biographical context of the conversation, can easily believe that Heidegger's understanding of kotoba and other mentioned aspects related to Japanese culture are genuine interpretations. However, it is interesting to note that Tezuka's biographical description of their meeting suggests that Heidegger made use of a much freer interpretation of Tezuka's explanations, especially regarding the meaning of the word kotoba (Tezuka, 1996: 62). Here I would like to emphasize the need to distinguish the content of the actual encounter from the philosophical essay. According to Tezuka's report, the encounter does not seem to result in a genuine philosophical dialogue. The essay, which is loosely based on the same encounter, however, tries to show the way towards an appropriate philosophical dialogue. In other words, the two texts have different purposes and interests. In the German text, Heidegger is named "the Inquirer" (F: Fragende) and Tezuka as " $a$ Japanese" (J: ein Japaner). The sense of anonymity conveyed here must be on purpose, precisely because Heidegger wants to highlight that what is at issue is a fictional piece of writing. Heidegger has no interest in reporting the details of the actual encounter that took place between him and Tezuka. Therefore, the fact that Heidegger's essay differs from the actual encounter cannot be used as an argument against Heidegger to claim that there was not a real dialogue between the two interlocutors. Nonetheless, this does not mean either that the overall framework of the philosophical conversation is obvious, which requires further hermeneutic scrutiny. The answer regarding the true content and subject matter of the dialogue, as well as its philosophical intentions and results, is somewhere between the informal meeting and the published philosophical essay.

To appropriately make sense of Heidegger's conversation with Tezuka, let me clarify the hermeneutic background of the essay. First, we should note that the original title of the essay conveys a different meaning compared to its English translation - A Dialogue on Language - as it literally says Aus einem Gespräch von der Sprache: From a conversation of the language. As such, the title of the English translation is not fitting considering the main ideas that are issued in the essay. As Parkes astutely notes, "the interlocutors strive to avoid speaking about language, trying rather to let the conversation be led by and issue from the essential being of language itself (vom Wesen der Sprache her)" (Parkes, 1987: 213). While the piece is placed at the beginning of the English translation of US, in the German original it appears as the third essay, preceded by Die Sprache (The Language) (1950), which is not included in the English translation, and Die Sprache im Gedicht: Eine Erörterung von Georg Trakls Gedicht (Language in the Poem: A Discussion on Georg Trakl's Poetic Work) (1952). ${ }^{9}$

The order in which the essays are presented to us in Heidegger's work has important hermeneutic implications with regard to the possibility of an appropriate understanding of the conversation. For instance, the first essay of the book problematizes the question of language from a topological standpoint (Ziarek, 2013: 135) by making an issue of our standing within the limits of language. Here Heidegger attempts to develop a hermeneutic "method" of interpreting the poetic essence of language, which requires

\footnotetext{
${ }^{9}$ In the dialogue, the inquirer lets his interlocutor know that "he kept the lecture appearing in print", hesitating about the fact whether he managed to avoid speaking about language in this lecture (US 139/49), which may be the reason why Hofstadter decided to leave this essay out.
} 
a confrontation with our relation to language. The second essay offers an exegetic analysis of Trakl's poetry while still operating against the background of the first essay.

The two essays are complementary in a way that they introduce and put to work the very idea of Erörterung, which can be roughly translated into English as "situating-discussion" or "discussion that situates". Heidegger writes: "Die Sprache erörtern heißt, nicht so sehr sie, sondern uns an den Ort ihres Wesens bringen: Versammlung in das Ereignis" (US 10). Albert Hofstadter translates the sentence as follows: "To discuss language, to place it, means to bring to its place of being not so much language as ourselves: our own gathering into the appropriation" (Heidegger, 2001: 188). However, an alternative translation could emphasize the key issue more explicitly. My own translation would run as follows: "Discussing language does not so much mean situating it (language), but rather bringing ourselves into the place of its essence: gathering in the appropriation". It is no coincidence that the second essay also starts with a series of topological remarks that discusses the relationship between Erörterung as "situating-discussing" and Ort as "place" (US 37/159), problematizing the site of Georg Trakl's poetry. What must be emphasized here is that our relation to that which we are trying to interpret depends on the place of thinking. The task is not to place an object in front of us to have a better view of it, but rather to situate ourselves in accordance with the way in which it shows itself to us. Such a change in orientation is also what is necessary as a change in our comportment towards the core matter of the conversation between Heidegger and Tezuka.

Within that context, it can be stated that Heidegger's essay has two dimensions. First, Heidegger problematizes the ground and horizon of a thinking dialogue with Japanese philosophy. Here, the implicit goal of Heidegger is to arrive at the openness of language to be able to interpret the Japanese word kotoba (言葉). Second, Heidegger presents his interpretation of the word kotoba, which translates as "foliage of speech" (Ma, 2007: 177) or more literally as the "leaves of things" (Marra, 2004: 562) in line with his own thought of a thinking conversation that emerges from stillness. The latter becomes possible as far as the first is attended. We need to avoid seeing the dialogue not as an attempt to designate a notion of language as if the aim was to bring up a "philosophy of language". With these preliminary remarks, now it will be easier to conceive what is stake in the conversation between Heidegger and Tezuka with regard to Heidegger's relation to Japanese philosophy and the notion of kotoba.

\section{The Way of the Conversation: The Way to kotoba}

The first necessary step in interpreting the conversation is to acknowledge silence, or perhaps more appropriately said, stillness (Stille), as the essential characteristic of the speaking of language. ${ }^{10}$ Before we come to speak about language, language itself speaks via stillness as we become its listeners and interpreters. ${ }^{11}$ Thus, the Inquirer asks:

\footnotetext{
${ }^{10}$ Heidegger specifically underlines this point in italics: "Die Sprache spricht als das Geläut der Stille" (US 27/205).

${ }^{11}$ Kotoh astutely summarizes the role of stillness/silence in Heidegger's later thought: "It is not logos, but the silence as the "basic mood/voice" (Grundstimme) that encounters the wonder of the presencing of being." His concluding remarks are worth reconsidering: "One should listen [...] belongingly to the sound of silence, which constantly emanates from the depths of the indescribable, and continue to let this be the source of one's own language" (1987: 211).
} 
I: What does the Japanese world understand by language? Asked still more cautiously: Do you have in your language a word for what we call language? If not, how do you experience what with us is called language?

$\mathrm{J}$ : No one has ever asked me that question. And it seems to me also that we in our own Japanese world pay no heed to what you are asking me now. I must beg you, then, to allow me a few moments of reflection. (The Japanese closes his eyes, lowers his head, and sinks into a long reflection. The Inquirer waits until his guest resumes the conversation.)

(...) There is a Japanese word that says the essential being of language, rather than being of use as a name for speaking and for language. (US 108/23)

Obviously, as Heidegger was drafting the essay, he already knew from their actual encounter that the Japanese word at issue was kotoba. However, at this point of the dialogue, this "wondrous word" is not given away. If Heidegger's goal was to merely provide an aesthetic image of the Japanese word for language, he could have done this at the very beginning by discoursing about the word kotoba, which is clearly not the case. Here we should also note the theatrical air that we hear in Heidegger's words. Heidegger's Japanese colleague takes his time as he "sinks into a long reflection". What Heidegger wants to emphasize is that an ideal philosophical conversation cannot be a hasty exchange of opinions and information. Both interlocutors take their time, which frees the necessary space for thought. Thus, Heidegger's interlocutors resist saying the word kotoba explicitly until it becomes impossible to retain the word any longer.

As the Inquirer and the Japanese think that it may be too early to venture an interpretation -since they may come to objectify the Japanese word for language as a mere definition of language- they change the topic, bringing us to the enigmatic role of the notion of $i k i$ (粋). While it is usually thought that the discussion on iki does not add anything significant for the concerns of the conversation, this would mean that we are missing an essential point. The way in which the notion of $i k i$ is introduced during the conversation is key to understanding the nature of the thinking dialogue, ${ }^{12}$ in the same way that the meaning of kotoba comes to the fore via the stillness of the conversation. Although the notion simply means '“chic' or 'elegance', or, as an adjective, 'elegant, chic, delicate, smart, pretty, refined, tasteful"” (May, 1996: 19), as we shall see, Heidegger's version significantly differs. In the conversation, we confront the difficulty of talking about the meaning of $i k i$, which results from the lack of a common horizon of understanding. In other words, Heidegger's introduction of $i k i$ has a specific purpose: it is intended to help the readers to realize the hermeneutic possibility of making sense of kotoba. Recalling his earlier conversations with Kuki, who is represented as a former colleague and student of his (although biographically this is not the truth), the Inquirer reminds to the Japanese about the similar kind of difficulties that he faced himself:

I: The danger of our dialogues was hidden in language itself, not in what we discussed, nor in the way in which we tried to do so. (US 85/4)

\footnotetext{
${ }^{12}$ Parkes claims that "there is no inherent connection between iki and koto" (1987: 215). Yet he also adds that thinking the meaning of koto as the matter (Sache) of language is what brings out the stillness of iki, while reflecting on the stillness of iki refers us to kotoba itself.
} 
The obvious danger at hand was that the language of the dialogue would shift everything into European discourse. The hermeneutic problem is clear: if iki is a Japanese expression, and, if the language of the dialogue is German, then how one should interpret the meaning of $i k i$ within the boundaries of the German language? How can we avoid transforming the original context and background of the Japanese conception and refrain from interpreting the meaning of $i k i$ from a horizon of understanding to which it does not belong? Stated otherwise, what must the middle ground of the discussion be, which will gather its interlocutors in the same openness of language ${ }^{13}$ The question does not have a predefined answer, since no pre-conception of language must guide and pre-determine the way of thinking. What that implies is that we must arrive at the way of language by allowing our subject matter, that is, language, to orient us within the context of the inquiry. As such, the act of listening, which takes place in and through stillness, is the more originary ground of any dialogue, which is why the Japanese suggests:

$\mathrm{J}$ : We Japanese do not think it strange if a dialogue leaves undefined what is really intended, or even restores it back to the keeping of the undefinable. (US 95/

13)

Here it can be seen that according to Heidegger, the Japanese has a completely unique experience of "conversation" -and of language- in comparison to speakers of Western languages. As the interlocutors search for a way to clarify the meaning of $i k i$, the guiding question turns out to be: "how European aesthetics might be suitable to give a higher clarity to what endows our art and poetry with their nature?" (US 95/13). Although the difference between the sensuous and the supra-sensuous figures in the Japanese aesthetics in an equivalent way in Western metaphysics, the nuance itself can be hardly grasped from the standpoint of European languages and metaphysical concepts that are at work. In that regard, interlocutors call the way in which the words grant themselves in the dialogue "a delicate gesture", namely, a beckoning, or hinting (winken). What we achieve when we say something amounts to a specific mode of "showing". Showing here does not simply indicate a linguistic process of signification, but rather it means letting the other see. One example of such a gesture comes from the Japanese $N \bar{o}$ drama. ${ }^{14}$ Heidegger's Japanese interlocutor reminds us that the Japanese scene is often empty, which requires the uncommon concentration of the spectators. Again, since what is of utmost importance in a thinking dialogue is letting the stillness speak, the Japanese way of attending is put forward as the ideal way of letting and space-making. Accordingly, the Japanese adds that even the slightest hand gesture of the actor must be attended in a particular way:

\footnotetext{
${ }^{13}$ Here I am here referring to Gadamer's idea of language as die Mitte, which is the middle ground that gathers its interlocutors where a common horizon of understanding emerges for understanding (Gadamer, 1999: 384, 387).

${ }^{14}$ As May shows evidence (1996: 17-18), Heidegger's real source in identifying this element in Japanese culture is German professor of Japanology, Oscar Benl, specifically his 1952 treaty, Zeami Motokiyo and the Spirit of Nō Drama: Esoteric Aesthetic Writings from the Fifteenth Century.
} 
$\mathrm{J}$ : For instance, if a mountain landscape is to appear, the actor slowly raises his open hand and holds it quietly above his eyes at eyebrow level. May I show you?

I: Please do.

(The Japanese raises and holds his hand as described.)

I: That is indeed a gesture with which a European will hardly be content. (US $102 / 18)$

The European spectator is not content, because he is used to the expressive movements of the European performer, which objectifies the phenomenon in bringing it into view. The Japanese performer, however, points towards the emptiness that encircles phenomena, which is the undefinable openness from which phenomena appears in their own way. When the gesture emerges from emptiness, one needs a kind of attentiveness that is attuned to the boundlessness in question. The receptivity that is necessary allows the "hint" to move freely from emptiness. Here, Heidegger's critique of the technicalaesthetic mode of representation that imprisons objects, events and landscapes in "frames" comes to the fore, as he suggests that "the East-asian world, and the technical-aesthetic product of the film industry are incompatible" (US 100/17). According to the Inquirer, there can be no such thing as Japanese cinema, since "photographic objectification is already a consequence of the ever wider outreach of Europeanisation". Here we can argue that the discussion of the delicate gesture that exists in the $N \bar{o}$ drama illustrates the kind of relation that one needs to hold to what is beckoned in the dialogue, which requires the same kind of attentiveness for the interpretation of the word kotoba. Hence, Heidegger's interlocutors designate $i k i$ as "grace", in the sense of the "pure delight of the calling stillness" (US 134/44). Iki is interpreted as the expression of the aesthetic gesture that by which we bear and encounter the emergence of a thing from emptiness or nothingness. ${ }^{15}$ In other words, $i k i$ opens the way to kotoba. The way of a "thinking conversation" requires a collaborative act of non-violence and letting. ${ }^{16}$

In the existing literature, the question as to whether we can speak of a genuine dialogue between Heidegger and Tezuka has received mixed answers. In general, there are two lines of thinking. The first approach deals more with the form of the dialogue (May, 1996) while the second focuses more on the content (Marra, 2004). On the one hand, Reinhard May's account shows in detail why the actual encounter differs highly from the content of Heidegger's essay. May astutely draws attention to the following point in regard with the existing scholarship on the essay: "In any case, it has

\footnotetext{
${ }^{15}$ Heidegger's emphasis on the stillness of language as the true mood or attunement (Stimmung) and voice (Stimme) of our saying is an important idea, and offers a strong critique of the traditional logocentric notion of language observed in Western metaphysics from Aristotle to Humboldt in various forms. Heidegger's turn toward stillness as the essence of language is also a turn toward no-thingness as the essence of being. In that context, what Heidegger's essay establishes is a shift in thinking by moving from phenomenological ontology to hermeneutic meontology, that is, moving from the thinking of being to the thinking the place of non-being, or nothingness. This can be traced back to Heidegger's famous inaugural address What is Metaphysics (1929), delivered at the University of Freiburg.

${ }^{16}$ In a certain sense, such a conversation involves what Gadamer calls the "fusion of horizons" (1999). If the language of the conversation is the primary language of one of the interlocutors, the speaker of the host language must be ready to appropriately accommodate the other interlocutor, which may mean, being open to be transformed linguistically.
} 
apparently not been suggested that the text represents exclusively Heidegger's own work, and that all passages in it are thus to be ascribed to Heidegger himself" (May, 1996: 13). ${ }^{17}$ In addition to that, point, May points towards the influence of Laozi's and Zhuangzi's ideas on Heidegger, especially with regard to the notion of "the waymaking of language". On the other hand, the commentary of Michael Marra (2004) provides a philosophical answer to the question that Heidegger poses in the essay: what is the Japanese word for language? (Marra, 2004: 555). In Heidegger's essay, Tezuka's answer to that question is kotoba, in the sense of "petals that stem from koto" (US 136/ 47) (more on this below). Since a comprehensive understanding of the meaning of kotoba requires an interpretation of koto, Marra goes on to offer a detailed study of the difference between the concepts of koto and mono to differentiate the thinghood of things from particular things as entities, similar to Heidegger's ontological difference between Sein (being) and Seiende (beings) (Marra, 2004, 556).

Now, while it is true that the meaning of the word kotoba plays a significant role in Heidegger's essay, Heidegger does not stand in an appropriate hermeneutic position to be able to interpret the Japanese word for language. Heidegger's lack of proficiency in East Asian languages drew him back from engaging with Japanese and Chinese in a more direct way. (Ma, 2007, 146-148). And this is related to the fact that the discussion about the meaning of kotoba first appears through the middle section of the conversation, taking up a more principal place only towards the end of the essay (US 108/45). The hermeneutic possibility of discoursing on and about language first depends on the possibility of establishing a ground for mutual understanding. The very meaning and philosophical implications of kotoba must show itself in accordance with the "waymaking" of the conversation.

\section{Heidegger's kotoba: "Leaves of Speech"}

As the Inquirer brings back in focus the hinting of the "beckoning stillness", the Japanese offers a preliminary interpretation of kotoba:

J: Up to this moment I have shied away from that word, because I must give a translation which makes our word for language look like a mere pictograph, to wit, something that belongs within the precincts of conceptual ideas: for European science and its philosophy try to grasp the nature of language only by way of concepts.

I: What is the Japanese word for "language"?

$\mathrm{J}$ : (after further hesitation) It is "Koto ba."

I: And what does that say?

$\mathrm{J}$ : $b a$ means leaves, including and especially the leaves of a blossom-petals. Think of cherry blossoms or plum blossoms. (US 134/45)

It must be acknowledged that the word kotoba has an interesting yet complex etymological background, and Heidegger's interpretation adds a second layer of complexity.

\footnotetext{
${ }^{17}$ May mentions Michiko Yoneda's work Gespräch und Dichtung: Ein Auseinandersetzungsversuch der Sprachauffassung Heideggers mit einem japanischen Sagen as a similar approach (May, 1996:14n1).
} 
His interpretation is not an interpretation that prioritizes philological accuracy, but rather poetic creativity. On the one hand, the second part of the word ba (ha) simply means "leaves" of a tree or a flower and can invoke a sense of density and abundance. Heidegger's Japanese interlocutor interprets this as the "leaves of a blossom", which is linguistically not necessarily the case. On the other hand, Tezuka himself writes that the sense of koto at issue is related to kotogara (事柄) meaning “event", thus the koto of kotoba is twofold: koto as matter or thing and koto as the expression of that happening (Tezuka, 1996: 62). Graham Parkes explains the etymology of kotoba by drawing on the Chinese characters that we see in the Japanese word. Accordingly, the first part, koto, signifies the sense of end and origin, -edge or border- beginning and end (Parkes, 1987: 214). It should be interesting for Heidegger to observe a semantic parallel between the German Ort and the Japanese koto, as the German word for place Ort also has a similar meaning of edge and limit. ${ }^{18}$ In that vein of thinking, for Heidegger, the word kotoba implies the "emergence of the flower petals" in their journeying from silence to speech and vice versa. Indeed, for Heidegger, what matters the most is to be able to elucidate the primordial emergence of a thing (Ding) as a meaningful entity. Accordingly, the word reflects the emergence of our experience of the manifestation of phenomena, arriving to the sign as the sounded word. The journey of words springs from silence, passes through signs, and descends back to stillness -for the sign can never exhaust the subject matter of our speech. Stated otherwise, the dictionary words touch upon the matter of our speaking, but they cannot capture the movement of saying. Thus, we need the poetic word, and in fact, poetic speech consists of "hints" that un-conceal a way toward the site of where things occur meaningfully. They can no longer be treated as mere signs. In this locus, thinking by listening, or as one might even say, thinking as listening occurs, which is the nature of language that admits us into the limits of a dialogue.

Heidegger's poetic interpretation can be more specifically called poietic in that it creatively aims to make-space for a new interpretation of language: the words' journey toward stillness is also their homecoming, which is the same journey of the petals descending back to the earth. When koto and ba are put together, kotoba expresses the verbal essence of language in the sense of bringing things into language, describing the emergence of words in abundance from and through stillness. The notion that Heidegger wishes to emphasize here implies that the core issue of language is not only a transfer of meanings from one mouth to another, which the more ordinary word for language gengo (言語) could convey (Marra, 2004: 555), but the very unfolding of meaningfulness itself that underpins the very origin of any understanding. The movement that saying enacts in language is the same gathering of the roots and the blossoming petals in and of place. The topological dialogue between the place and the way of language should not escape our attention: the upward movement from the roots to the petals embodies the downward movement from the petals to the roots. The flower petals that silently blossom from the earth are the words that offer themselves as the beckoning of the earth. The white and rose petals of plum and cherry blossoms are

\footnotetext{
18 "The idea of place as tied to a notion of gathering or 'focus' is also suggested by the etymology of the German term for place, Ort, according to which the term originally indicated the point or edge of a weapon the point of a spear, for instance - at which all of the energy of the weapon is brought to bear" (Malpas, 2006: 29).
} 
the hints of the fruits. The word, belonging to the domain of the nameless, emerges freely from the place and becomes the way of the conversation. ${ }^{19}$

Upon the Japanese interlocutor's designation of kotoba as "the petals that stem from koto", the Inquirer states that "That is a wondrous word, and therefore inexhaustible to our thinking. It names something other than our names, understood metaphysically, present to us language, glossa, lingua, langue" (US 136/47). Here Heidegger can indeed be criticized, as it is not clear as to how and why the Japanese word should be exempt from our metaphysical way of thinking about the nature of language. For instance, the metaphysical essence of the word "being" does not lie in what it signifies, rather in how we happen to make sense of it as the ground and essence of beings (rather than the inexhaustible manifestation of the meaningfulness of things). Likewise, the word language itself, whether expressed as kotoba or Sprache, is neither metaphysical nor non-metaphysical in itself. In the later stages of the essay, as the Inquirer hesitates to speak more directly about the meaning of kotoba, the Japanese interlocutor finds himself in an odd position. While it was previously the Inquirer who adopted the more hesitant comportment, now, despite the Japanese interlocutor's willingness to elaborate on the implications of kotoba, he takes a step back. This theatrical interplay of hesitation and reticence leads the interlocutors back to reconsidering the nature of a dialogue, which is represented as the "hermeneutic circle" (US 142/51). At this point, we reach the limits of the dialogue on kotoba:

I: A dialogue that would remain originarily appropriated to Saying.

$\mathrm{J}$ : But then, not every talk between people could be called a dialogue any longer.

I: ... if we from now on hear this word as though it named for us a focusing on the reality of language.

J: In this sense, then, even Plato's Dialogues would not be dialogues?

I: I would like to leave that question open, and only point out that the kind of dialogue is determined by that which speaks to those who seemingly are the only speakers-men. (US 143/52)

As can be seen, the conversation remains open to the domain of the unsayable. This is the ultimate point of the dialogue, which arrives at the topos of reticence: silence about silence, or rather, stillness about stillness. The dialogue leaves us thinking about the essence of the twofold nature of language and stillness, while problematizing the nature of a thinking conversation. In the next and concluding section, let me involve Ueda in that conversation to deal with the relationship between the stillness of words and our poetic experience of the world. In doing so, we can leave behind Heidegger's preconception that the Japanese word for language tends to be a non-metaphysical one only for being a non-Western word. As such, the meaning of kotoba can also be elucidated from a Japanese point of view.

\footnotetext{
${ }^{19}$ May states that Heidegger's dialogue can be read as his account of dao as "the Way" (May, 1996: 20), a concept which indeed appears in the later essays of US (187/98).
} 


\section{Ueda's kotoba: The Two-Way Movement in Language}

Can we ever be silent about silence as Heidegger and Tezuka concluded? What kind of a topos would that be? The third generation Kyoto School philosopher Ueda Shizuteru's thought of language engages precisely with these issues relating to the nature of human subjectivity. Bret Davis locates Ueda's philosophy, along with the latter's predecessors Nishida and Nishitani, within the philosophical conversation between Zen and Western philosophy (2019: 714). In relation with that it must also be underlined that Ueda's thought of language has topological underpinnings, which are obviously in dialogue with Nishida and Heidegger. In a nutshell, the primary objective of Nishida's philosophy was to locate the pure experience of things in the world via his "logic of place" (basho no ronri 場所の 理) beyond the confines of the perennial object-subject dichotomy. According to Nishida's philosophy, a pure experience can take place in a state of being where one does not identify oneself as a subject over and against objects. Within that regard, by placing philosophy of Zen in a dialogue with the Western thought, the aim of Ueda's philosophy of language is to identify the relation between experience and expression. Dealing with Ueda's account at this point will help clarify my arguments on Heidegger's dialogue with Japanese philosophy, while providing a more complete account of the notion of kotoba.

Ueda's philosophy of language situates in a field where important aspects of hermeneutic phenomenology and Zen coincide. Davis suggests that one of the basic issues of Zen for Ueda was the necessary commuting between silence, as demonstrated in seated meditation (zazen 座禅), and speech, as appears in the verbal encounters with teachers, which may include the reciting of köans. (Davis, 2019: 714). We can clearly see that lively tension between silence and speech in Ueda's thought, as he writes:

The words of language (kotoba) show things, events, or states-of-affairs (koto). Words express or manifest things; at times they can be said to manifest while expressing them. Therein lies the power of language. Moreover, as things are revealed, they disappear as words. This is the wonder of language. In the process of showing something, a word disappears as word and in its place something appears as something. (Ueda, 2011: 766)

What that means is, most of the time we hear meanings, that is, that which is signified, but not the language itself. In turn, as soon as we try to hear language itself, we lose the ordinary meanings. In that sense, as Ueda argues explicitly, language appears both as that which makes possible the experience of a world and that which limits our experience of it (Ueda, 2011: 766). If so, what is the relation between the world and language? For Ueda, being-in-the-world, a notion that he draws from Heidegger's early thought, is fundamentally two-fold. While the meanings in the world are constituted linguistically, there is also a second dimension of the world which is pre-or even nonconceptual. This topos, which Ueda calls "hollow expanse", encompasses the two-fold nature of the world and language, and is the source of a pure experience of the world. Let me expand on that.

Explaining his two-fold view of the world, Ueda interprets the poem of a fourth grader who lived near the lake Nojiri in Nagano prefecture. The title of the poem is "Evening Glow", which reads and is translated as follows: 
Kurohimeyama to Myōkōsan no ma ni hi wa shizumu

Sonotoki mikan-iro no kumo ga

Sūtto watashi no me no mae o tōru

Ichinichi no dekigoto o nosete kumo wa ugoku

Watashi ga gakkō de benkyō shite ita no wa

Mite irudarou $\mathrm{ka}$

The sun sets between Mt Kurohime and Mt Myōkō;

Just then an orange cloud

Smoothly passes before my eyes.

Carrying the day's events, the cloud drifts along.

I was studying at school-

Is it watching that, I wonder? (Ueda, 2011: 772).

Ueda draws our attention to the fourth line of the poem, which apparently shows a significant contrast with the preceding three lines, where mere "state of affairs" of this world are described. However, the fourth line, "Carrying the day's events, the cloud drifts along", does not only designate what things are, but brings our attention back to the way in which the world becomes a matter of experience in language. It is key to note that core matter of the fourth line can only be said in language: "The clouds carry the day's events, drifting along". This is not a mere description of the things in the world, namely not an "event" that is readily available to our understanding. It is only accessible through the happening of kotoba itself. What that means is that language expresses a "hollow" thing (Ueda, 2011: 774) that is distinct from things themselves. The nature of things must be experienced by commuting this hollow expanse of meaningfulness, which is implicated in the last line: "Is it watching that, I wonder". Here, one is no longer the subject of the act of seeing, but one becomes the object of the cloud. By taking a step back from the place of one's ego, which constitutes the ordinary knowledge of world, one finds oneself in the place of pure experience as a "selfless self". Ueda describes this as follows: "While actually existing in the world, at the same time we hollowly exist in the limitless openness in which the world is located. By means of language we, who are located in this twofold manner, come to awaken to our actual hollow existence" (Ueda, 2011: 776). According to Ueda, "hollow words", which are preserved essentially in poetic language, can hint to us the nature of language, as well as our being placed in language where human subjectivity appears as a "no-self" (Ueda, 2011: 765-766). Hollow words, then, allow us to understand the meaning of words, while also providing the space to make sense of the happening of language itself from "nothing" ( $m u$ 無) (Davis, 2019: 718). This is indicative of a marriage of a hermeneutic-phenomenological manner of thinking with a philosophy of Zen, both of which are expressed in topological terms, denoting how and why the issue is linked with the place and limit of language. The happening of kotoba is the same as the happening of the world in its two-fold nature. In that context, Ueda's interpretation of the fourth line of the poem refers to the limit-experience of language where the hermeneutic movement I have mentioned emerges from stillness and returns to stillness via words. 
The hermeneutic movement at issue revolves around the limits of language, and in that regard, it encompasses the linguistic core of language from inside and outside. Let me clarify that from a topological point of view. The fourth line reads: "The clouds carry the day's events, drifting along". According to Ueda, this is where we enter into language, while at the same time exit from it where the signification of worldly objects occurs. While exiting from the boundaries of the world, we enter into the hollow expanse from which our originary experience of the world originates. The fourth line, thus, is what opens our understanding to language itself, while also delimiting our ordinary-everyday understanding of things and events. In turn, the fifth and the sixth lines bring us back to the world, yet this time from the opposite direction of the hermeneutic movement. We are no longer the observer and the subject of the familiar world in which we are. It is still the same world, it is the same cloud that we are seeing, but our perspective has been oriented in a new way. As the subject, I am studying in the school, though the question as to whether the cloud sees me, cannot be answered from the boundaries of our ordinary experience of the world. In a certain way, such a reflection transcends the world of state of affairs, while also incorporating it into its essence. The question implicates a meditative comportment toward the world, which makes space for a unique experience of being-in-the-world. Ueda considers such an experience to be a religious one, as we can observe especially in mysticism, as well as in Zen thinking (Ueda, 2011: 770). ${ }^{20}$

For Ueda, a pure experience of the world in Zen specifically means a journeying between where we find ourselves in the everyday world and the place of nothingness. Put differently, our ordinary world is enveloped by the topos of original nothingness. We should be careful here as not to place the mystical experience of the world merely against the ordinary experience of the world. This is precisely where we the see the necessary two-way movement at stake: ordinary language allows us to experience the ordinary world, which is where the mystical experience of the world emerges. In turn, from the mystical experience of the world, we are referred back to our ordinary world. The hollowness and actuality at hand are intertwined through a constant interplay. Altogether, this amounts to the notion of language not as a mere system of signs, but as the place of a hermeneutic movement in and through which a pure experience of the world turns out to be possible.

As I have indicated above, Ueda's idea of language can be made sense of from a topological point: language involves both "space-making" and "limitation". Inasmuch as the world is opened up through words, it is also bound by them. For Ueda, language can be distinguished from the world, even if the meaning of space in question is primarily accessible via linguistic expressions. In that sense, the question whether the nature of language is inside or outside of language is important. At first, there seems to be two possibilities, which are two extreme views: (1) Everything remains inside of language, because even the question concerning the nature of language appears within the boundaries of language. (2) We can move outside of language, since language is only an instrument that obstructs our access to the pure experience of phenomena. Yet,

\footnotetext{
${ }^{20}$ Davis explains this point as follows: "Zen is not an otherworldly mysticism; it is rather a "non-mysticism" (G. Nicht-Mystik, J. hishinpi-shugi 非神秘主義) or “de-mysticism” that repeatedly passes through and beyond a silent state of unio mystica on the way back to a nondual (that is, "not one and not two") experience of living in the linguistically articulated world of plurality (Davis, 2019: 717).
} 
Ueda offers a third way: the dynamic movement of "exiting language and then exiting into language", (Ueda, 2011: 768) which is a movement only the poetic language permits. The poetic essence of language signifies the movement from and into silence, where the core matter of words becomes explicit, yet, neither "within" nor "outside" of language, but at the very limit of language. This is an experience that strikes us in situations when we feel the need to say "Oh!", namely when we are at a loss for words. Ueda writes: "Language is torn through into silence and silence is torn through into language. It is precisely this movement that is primordial experience, which altogether I understand as a living wellspring of the death and resuscitation of experience" (Ueda, 2011: 768). This occurs precisely when we experience the gap between the "word" and the "thing", a topos which Ueda defines to be the hollow space of "nomeaning" (2011: 769). The two-way movement that becomes apparent in poetic words signifies the movement from language into silence and vice versa. This is where the core matter of language becomes explicit, neither "within" nor "outside" language, but at the very "limit" of our dialogue with language. As such, the movement at stake is not a "smooth and automatic" one, it is a movement of "twofold breaking through". (Ueda, 2011: 768).

When we experience the void between "words" and "things", the experience of the world overflows us; this is the pure experience of the world. To put otherwise, the world makes sense to us in a genuine way especially in moments when we can place ourselves in the constant dialogue between words and things. What that means is, the pure experience of the world amounts to neither "things-in-themselves" signified with pure words, nor solely to their ordinary representations, but to the experience of being placed in the dynamic between. In poetic language, we become the listeners of that dialogue. This is also the dialogue between the sayable and unsayable, the hollow and the actual, which displays a back-and-forth movement that is preserved and embodied especially in Zen thinking between "zazen and sanzen" (Davis, 2019: 728), reflecting the stillness of language and the speaking of stillness.

In that regard, let me draw a similarity between Heidegger and Ueda's way of thinking language. Heidegger's interpretation of kotoba involves a similar attempt of exiting into and from dialogue, calling us to confront the boundaries of our world of meaning. Heidegger specifically mentions the idea of the "way-making movement" of language (Be-wëgung) in his work (US 186/91), which amounts to the un-concealment of the event of language in the dialogue between dictionary words and poetic words. When we let the language speak of itself, it speaks through us via stillness; when we speak about language, it stops speaking of stillness and becomes simply mute. While for Heidegger, an authentic mode of saying needs to be silent about silence and saying is the disclosure of the way of saying, for Ueda, the authentic self is selfless, endowed with an experience of the two-foldness of the world. Ueda's idea of language comes to the fore in its full clarity as he writes: "language is indeed the seal of self-awareness of a human being's actual existence and hollow-existence within a twofold hollow-expanse/ world" (Ueda, 2011: 775). In a similar vein of thought, in Heidegger's essay the interlocutors converse not only about the nature of a language, just as they are not only silent about the meaning of a dialogue. What is at stake goes beyond the limits of a mere inter-subjective communication. The more profound significance of the dialogue, therefore, lies in the movement that occurs between the hollow expanse and the ordinary world. It can be argued that through his essay Heidegger wishes to point 
toward the pre-subjective and pre-objective topos of the dialogue, namely to its waymaking and appearance in the openness of language. This is similar to Ueda's idea of kotoba, as he writes, "while revealing beings and while reflecting being as a whole, words are "hollow words" that reflectively expose the hollow-expanse or "absolute nothingness" in which being as a whole is located" (Ueda, 2011: 778). This third level of meaningfulness, namely the space of no-meaning, envelops, first, the signification of things, and second, the signification of the world in which the event of language takes place. Only by our listening to the hollowness of actuality and the actuality of hollowness in their twofold correlation, can language freely move and become what it is.

\section{Conclusion}

The conversation between Heidegger and Japanese philosophy is situated in the region of "letting-be", which underpins the stillness of kotoba. Thinking with Ueda, we grasp the free space from which to see ourselves, namely, the perspective of the hollow expanse that shows forth the limits of language. With a similar conception of kotoba, Heidegger attempts to overcome the idea of a dialogue as a mere exchange of opinions and information. One of the most important conclusions that we can draw from this comparison is that all conversations first need their interlocutors to be in a conversation with the language itself. The true character of Heidegger's conversation with Tezuka, then, can neither be found in Heidegger's "actual" encounter with Tezuka, nor merely in Heidegger's "hollow" essay. Departing from Ueda's account of kotoba, it appears that a genuine conversation can only be located in the dialogue of actuality and hollowness, which finds it expression in the two-fold breakthrough of poetic language.

\section{References}

Davis, W. B. (2007). Heidegger and the will: On the way to Gelassenheit. Northwestern University Press.

Davis, W. B. (2013). Heidegger and Asian philosophy. In F. Raffoul \& E. S. Nelson (Eds.), The Bloomsbury companion to Heidegger (pp. 459-471). Bloomsbury Academic.

Davis, W. B. (2019). Expressing experience: Language in Ueda Shizuteru's philosophy of Zen. In: Kopf G. (Ed.), The Dao companion to Japanese Buddhist philosophy. Dao companions to Chinese philosophy, vol 8. Springer, , 713-738.

Davis, W. B. (Ed.). (2020). The Oxford handbook of Japanese philosophy. Oxford University Press.

Davis, W. B., Schroeder, B., \& Wirth, J. M. (Eds.). (2011). Japanese and continental philosophy: Conversations with the Kyoto school. Indiana University Press.

Gadamer, H. (1999). Wahrheit und Methode: Grundzüge einer philosophischen Hermeneutik. J.C.B Mohr (Paul Siebeck).

Heidegger, M. (1985). Unterwegs zur Sprache (GA: 12). Frankfurt am Main: Vittorio Klostermann. ([1971] on the way to language. Translated by Peter D. Hertz. New York: Harper \& Row Publishers).

Heidegger, M. (1993) Hölderlins Hymne: Der Ister (GA: 53). Frankfurt am Main: Vittorio Klostermann, 1993. Heidegger, M. (2001). Poetry, language, thought. Translated by Albert Hoftstadter. Harper Collins Publishers.

Heisig, J. (2001). Philosophers of nothingness. An essay on the Kyoto School. Honolulu: Hawaii University Press.

Hsiao, P. S. (1987). Heidegger and our translation of the Tao te Ching. In G. Parkes (Ed.), Heidegger and Asian thought (pp. 93-103). University of Hawaii Press. 
Inaga, S. (2013). Japanese philosophers go west: The effect of maritime trips on philosophy in Japan with special reference to the case of Watsuji Tetsurō. Japan Review, 25, 113-144.

Kida, G. (2014). 'Tetsugaku' to Wa nan de atta no ka" [What was "philosophy"]. In Kida gen: Keimyō shadatsu na han- tetsugaku [Kida Gen: Lambent and unconstrained Antiphilosophy] Tokyo: Kawade Shobō Shinja, pp. 40-52.

Kotoh, T. (1987). Language and silence: Self-inquiry in Heidegger and Zen. In G. Parkes (Ed.), Heidegger and Asian thought (pp. 201-211). University of Hawaii Press.

Krummel, J. (2013). On (the) nothing: Heidegger and Nishida. Continental Philosophy Review, 46(2), 239268.

Ma, L. (2007). Heidegger on east-west dialogue: Anticipating the event. Routledge.

Malpas, J. (2006). Heidegger's topology: Being, place, world. The MIT Press.

Marra, F. M. (2004). An answer to Heidegger's question. Philosophy East and West, 54(4), 555-568.

May, R. (1996). Heidegger's hidden sources: East Asian influences on his work. Translated by Graham Parkes. Routledge.

Mizoguchi, K. (1987). Heidegger's Bremen lectures: Towards a dialogue with his later thought. In G. Parkes (Ed.), Heidegger and Asian thought (pp. 187-199). University of Hawaii Press.

Morisato, T. (2019). Faith and reason in continental Japanese philosophy. , .

Parkes, G. (Ed). (1987). Heidegger and Asian thought. Honolulu: University of Hawaii Press.

Tezuka, T. (1996). An hour with Heidegger. In G. Parkes (Trans.), Heidegger's hidden sources: East Asian influences on his work. Routledge, pp. 61-66.

Ueda, S. (2011). Language in a twofold world. In J. Heisig, T. P. Kasulis, \& J. C. Maraldo (Eds.), Japanese philosophy: A sourcebook (pp. 766-784). University of Hawaii Press.

Ziarek, K. (2013). Language after Heidegger. Indiana University Press. 